\title{
THE BASE OF THE METHODICAL DESIGN AND IMPLEMENTATION OF ENGINEERING EDUCATION PROCESS
}

\author{
Renata Lis', Zygmunt Lenik ${ }^{2}$ \\ 1 Fundamentals of Technology Department, Lublin University of Technology, e-mail: r.lis@pollub.pl \\ 2 Department of Teaching Methods and Strategies, Lublin University of Technology, e-mail: z.lenik@pollub.pl
}

Received: 2012.11.08

Accepted: 2012.11.29

Published: 2012.12.21

\begin{abstract}
The article is devoted to the methodology of implementation of European and national qualifications framework in the academic process. It consists of: the methodic of design degree programs and classes and the methodic of the teaching process.
\end{abstract}

Keywords: methodology education, engineers.

\section{INTRODUCTION}

Learning is, together with working and resting, one of the basic human activities. It is said to last from birth to death. Learning is particularly important in information society in $21^{\text {st }} \mathrm{c}$. The effects of learning are knowledge, skills and competences. Learning is an intended, planned and systematic process (in case of incidental learning these features are not present). On the other hand, managing the learning process is called teaching.

Learning and teaching together make the education process and are related to the development if a man as a whole. Education can be general or vocational at different levels. Engineers' education takes place at undergraduate higher education level, especially at technical schools. The effect of this process is to obtain the title of engineer.

Engineering education process is constantly undergoing modifications throughout the process, in accordance to the advances of sciences, technology and to comply with European Qualifications Framework and National Qualifications Framework. The works on unifying the system of teaching are conducted in over 120 countries at the moment.

\section{AIMS OF EUROPEAN QUALIFICATIONS FRAMEWORK}

The aim of European and National Qualifications Framework (EQF and NQF) is to unify education in the whole Europe, improve quality and effectiveness of education and to enable comparison of achievements and qualifications of students. According to the guidelines of Ministry of Science and Higher Education, universities in Poland prepare the teaching programmes, within their autonomies, in accordance with NQF.

The methodology emphasises the outcomes of teaching, which must be comparable between any European school, by the description of competences that are useful for work and further education. This requires the school to develop a module teaching programme and monitor the quality of its outcomes. This generates a chance to adapt the teaching programme to students' possibilities, expectations and predispositions as well as the labour market. The obtained qualifications in schools are the effects of learning in the framework of standards, completed with a diploma, certificate the title, etc. The standards include student's level and workload, materialised in ECTS points. The outcomes of education define what the student should know, understand, do after education process is completed. 
In National Qualifications Framework, alike in European Qualifications Framework, the effects of learning refer to knowledge, skills (including the skills of learning and communicating) and competences. In European Qualifications Framework for lifelong learning the outcomes of learning are defined in three categories:

- Knowledge that can be theoretic or factual. This includes a collection of facts, rules, theories and related practices with a specific field of work and knowledge.

- Mental (cognitive) skills - logical, intuitive and creative thinking and practical skills (concerning manual skills, using methods, materials, tools and instruments in order to make tasks and solve problems).

- Competences related to autonomy and responsibility [1].

The basis of teaching outcomes description in National Qualifications Framework is "the advancement in mastering knowledge in a given area, depth of understanding problems, refinement of practical skills, independence of actions and recognitions and evaluation of important ethical, social and professional issues" [1, p. 19]. In order to make students advance in their personal development in this form of teaching process, changes in teaching content and methods are necessary.

\section{DESIGNING TEACHING PROGRAMMES AND DIDACTICS}

Significant changes in the methodology of designing teaching programmes on the basis of outcomes have been made. Presently, former programmes based on teaching content developed on the basis of traditional methods are abandoned to "shift the emphasis from the teacher onto the learner, from teaching onto learning and from acquiring knowledge into developing skills and attitudes social and personal competences" [1, p. 19].

The procedure of designing educational programmes covers the following phases:

- Defining detailed effects of education corresponding to the diploma of a given educational programme. The effects are present in the following criteria: knowledge, skills, personal and social competences. In order to define them it is necessary to consider the mission and vision of the school, material and human resources.
- Developing the programme with a set of subjects, teaching content, intended education effects, forms and effects of education, teaching forms and techniques (lectures, activities, laboratory classes, project consultations, etc.).

- Verification and correction of initial education programme.

- Developing mechanisms of checking if and to what degree the intended effects of education are achieved in the process of learning [1, p. 92].

Developing teaching programmes it is necessary to consider documents regulating the aims, effects and content that result from them and finally the realisation requirements agreed for at European, National and school level. Detailed methodology of a new education programme is determined by the concept, planning and defining the requirements, design, implementation, testing and evaluation [2]. Designing education programmes and classes concerns designing a detailed description of the effects of learning with regards to the total knowledge and skill detailed description of the effects of learning with regards to personal and social competences. Then, the sets of content are developed, topics and contents are assigned to given subjects. Assigning the types of classes to these subjects. Describing (subject sheet, syllabi) defining the work load for individual student, expressed in ECTS points. One should remember that the effects of earning should be achievable in a given period of time, they should define the range of knowledge, levels of skills and competences, human and education resources. The effects of education implicate the range of content and evaluation methods [1]. In order to control the correctness of the programme, one can construct a matrix of teaching effects.

The presented changes in the approach to teaching process force changes in academic teachers' work by new approach to teaching activities that concerns supporting students in their independent knowledge, skills and competence gaining. Teacher's activeness is extended to cover students by organising and managing education process, rather than providing ready knowledge to be remembered. The teacher has a role of a manager who facilitates intelligent studying (coach/ facilitator). It is important for the school to evaluate the effectiveness of internal quality control system, i.e. achieving the aims of teaching. The 
range of accreditation agencies also changes, e.g. it can cover the products of examination: projects, graduation papers and other forms recorded in an electronic medium, e.g. the course of graduation exam, exercises, exams. This is why, teacher's work must be meticulously documented.

\section{METHODOLOGICAL FOUNDATIONS OF THE TEACHING PROCESS}

The superior aim of implementing changes is to increase the quality and efficiency of education. The aim is implemented by:

- The descriptions of teaching effects for all categories of knowledge, skills and competences in the subject sheet (syllabus).

- Proposal of methods used to achieve the objectives. The consist of aims and content of teaching, teaching methods, new role: extending the activeness from teacher onto students, methods of reporting the effects of teaching.

- Defining studetnt's workload and assigning ECTS points to given subjects.

- Methods of verifying the intended effects of education process, what includes formatting evaluation (shaping), summing evaluation and ipsative evaluation (self-assessment).

Teaching effects for a given subject concern knowledge, skills and competences that students obtain in the process [6]. They are pre-defined in subject description (subject sheet, syllabus) and are closely related to the student's work load expressed in ECTS points and the methods of verifying the effects of education. The sum of teaching effects from individual subjects constitutes the final qualifications of the graduate, according to the accepted standards, alumnus profile and crowned with an engineers' diploma.

The knowledge from given subject is constituted from scientific rights, rules, facts, theories, processes, phenomena, etc. On should add that after the classes, a student should be able to use the knowledge to describe, name, summarise, define, characterise, identify, verify, select, calculate, prove, explain, etc.

As far as the skills are concerned, they refer to performing tasks and solving problems, using the materials and tools, learning and communication skills. They should be drilled during every single class, depending on the subject. After the classes the student should be able to design, de- velop, analyse, formulate, interpret, control, plan, calculate, solve, use, perform, organise, cooperate, order, verify, search, use, etc.

Finally, competences show attitudes and are related to emotional and volitional intelligence, e.g. sensitivity, awareness, responsibility, ability to..., creativity, attention, justice, flexibility, morality, rightfulness, etc. These attitudes and features should be developed in every subject, considering its specificity.

The presented effects of education constitute student's holistic development: intellectual, volitional, social, cultural and emotional, which are manifested in his/her further actions. Student's personal development and his/her advancements in knowledge are considered directly in the subject description and results from the alumnus profile.

In the profile description (syllabus) it is necessary to point to the effects of teaching, ECTS points that define student's work load, according to the Boulogne standards and the guidelines of National Qualifications Framework [1, 4, 5, 7]. One ECTS point is c.a. 25-30 student's working hours, including their own work. One semester is c.a. 30 ECTS points. Prior to each semester, all academic teachers are obliged to prepare and submit a detailed project description (separate for each form of work). Example effects of engineering education with teaching rights in technical and computer education, technology and pedagogy are presented in Table 1.

Engineering education is based on four pillars of life-long learning [3]. They are:

- learn to know,

- learn to act,

- learn to live together,

- learn to be.

Modern engineer's education requires new approach of the teacher, who should not only emphasise knowledge but also skill and competences as well as practical use of the interdisciplinary knowledge for problem solving. The change in the function of a teacher concerns the fact that that he/she not only teaches but also supports a student in learning, organises learning and activates students. The teacher is an expert in his/her area and an enthusiast of the subject. They treat students as partners. They are always well prepared to classes in terms of teaching subject and methodology of work. 
Table 1. Examples of the effects of training for Education in Technology and Computer Science course with computer science, technology and education range

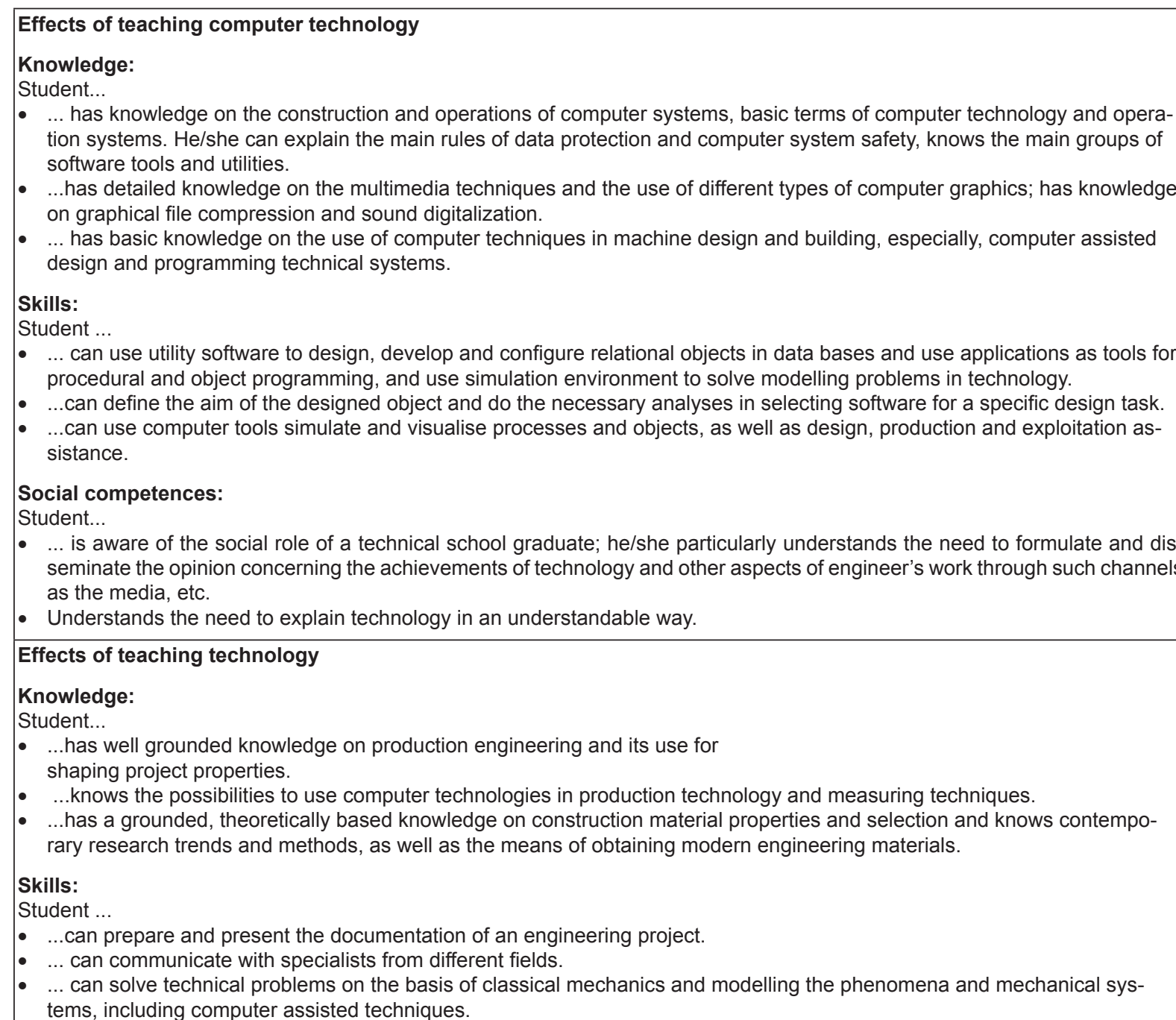
tems, including computer assisted techniques.

Social competences:

Student...

- ... is aware of the importance and understands technical and non-technical aspects and effects of engineer's work, including the influence on the environment and the related responsibility for the decisions.

- ... is aware of the importance of precision and solidity in designing and performing technical tasks.

\section{Effects of teaching pedagogy}

Knowledge:

Student...

- ... has basic psychological, sociological and pedagogical knowledge that allows him/her to understand the processes of development, socialization, up-bringing and teaching-learning.

- ... knows the didactic process and wants to organise it.

- ... has broad knowledge on technology didactics, computer technology and pedagogical activities with the use of comuter technologies.

Skills:

Student...

- .... can realise didactic, up-bringing and caring tasks of school.

- ... can adapt the technology and computer technology teaching programme to pupils' individual needs.

- ... can use basic psychological, sociological and pedagogical knowledge to analyse, interpret and solve educational and upbringing problems.

Social competences:

Student...

- ... is practically prepared to responsible realization of professional duties (didactics, up-bringing and caring) that result from the role of a teacher and an engineer.

- ... understands and knows the chances of continuous education, thus he/she gains new professional, social and personal competences (e.g. by graduate and postgraduate programmes, courses, etc. )

Source: Documentation of the Fundamentals of Technology Faculty. 


\section{CONCLUSIONS}

1. The realisation of teaching on the basis of teaching effects advised in European and National Qualifications Framework are beneficiary for student, teacher and future employer.

2. It influences higher education quality and efficiency.

3. It facilitates identification and elimination of gaps in the teaching programmes.

4. It gives larger autonomy to the university and at the same time, chances to experiment with and implement new didactic concept.

5. It allows for quick evaluation of students' achievements and detecting potential gaps in information, skills and competences.

6. It gives students higher possibilities to build individual education paths and realise the idea of horizontal and vertical mobility.

7. It allows testing and evaluation of programme at both the phase of planning and implementation - teaching effect matrix and competence matrix.

8. It give a quick access and orientation in education offer in the information and promotion materials for future students.

9. It forced the change of aims and teaching content, sets new roles for a teacher and student, proposes using new activating methods of teaching.

10.It emphasises the use of knowledge, skills and competences in practice.

\section{REFERENCES}

1. Autonomia programowa uczelni. Ramy kwalifikacji dla szkolnictwa wyższego. Pod red. E. Chmieleckiej. Wyd. MNiSW. Warszawa 2010.

2. Brenner E., Niehs J. Curricula Development based on Learning Outcomes - An Austrian Case. [In:] Implementing Competence Orientation and Learning Outcomes in Higher Education, ed. by E. Canon at al., 2008. http://www.he-leo-project.eu/ he leo-handbook/processes_and_practices/curricula-development-based-onlearning-outcomes2013-an-austrian-case/

3. Dolores J. Edukacja - jest w niej ukryty skarb. Raport dla UNESCO Międzynarodowej Komisji do spraw Edukacji dla XXI wieku. Warszawa 1998.

4. Feyo de Azevedo S. High Level Qualifi cations Frameworks and the EUR-ACE Frameworks Standards - do they fit together? Workshop on Overarching and Sectoral Frameworks, European Network for Accreditation of Engineering Education, Brussels, 22 January 2009.

5. Freeston I. Progressing Towards Global Standards in Engineering Education. Workshop on Overarching and Sectoral Frameworks, European Network for Accreditation of Engineering Education, Brussels, 22 January 2009.

6. Śniadkowski M. Kompetencje animacyjne nauczyciela szansą w oddziaływaniu wychowawczym. [W:] M. Gwoździcka-Piotrowska, A. Zduniak "Edukacja w społeczeństwie ryzyka. Bezpieczeństwo jako wartość", t. 2, Poznań 2007, 159-166.

7. Ziółek M.: Tworzenie programu studiów na bazie efektów uczenia się. http://ekspercibolonscy. org.pl/sites/ekspercibolonscy.org.pl/files/MZ_budowa\%20programow\%20studiow_070510.pdf 